\title{
DESIGN THINKING.
}

\section{MODEL PRACY BADAWCZEJ W OBLICZU \\ DZIKICH PROBLEMÓW NAUK SPOLECZNYCH}

Ewa Zielińska

Uniwersytet Warszawski

Richard Buchanan w eseju Wicked Problems of Design Thinking (1992: 6-8) stara się zarysować sytuację, w jakiej znalazły się sztuki piękne w XX wieku. Ze względu na ogromny wpływ technologii na proces twórczy w dziedzinę sztuki próbuje wkroczyć nowa forma artystycznego wyrazu design. Ten owoc rozwoju technologicznego zostaje jednak zdegradowany i odrzucony przez kręgi teoretyków i praktyków sztuk pięknych z powodu swojej istoty - nieprzystającej do wzoru, jaki owym sztukom przypisali dziewiętnastowieczni encyklopedyści (tamże: 5). W opozycji do charakteru swoich poprzedniczek design cechują bowiem powtarzalność i użyteczność, a refleksja twórcy o produkcie finalnym nosi znamiona myślenia praktycznego. Buchanan obstaje jednak przy tym, aby włączyć design w obszar sztuki. Nazywa go „sztuką wyzwoloną kultury technologicznej” (tamże: 19), zastrzegając, że pierwiastek „sztuki” jest w nim równoważny elementom naukowym i praktycznym.

Takim wprowadzeniem autor otwiera pole do dalszej refleksji, której osia jest próba odpowiedzi na pytanie, czym właściwie jest design? Wielość ujęć jego istoty, jak i płaszczyzn, na których się przejawia - komunikowanie symboliczne i wizualne, tworzenie przedmiotów materialnych, organizacja usług oraz projektowanie środowiska zamieszkania, pracy, nauki i zabawy (tamże: 9-10) - przysparza problemu teoretykom pragnącym jednoznacznie zaklasyfikować i zdefiniować to pojęcie. Buchanan zauważa, iż powtarzającym się błędem jest spoglądanie na design jedynie przez pryzmat produktów, a nie modelu pracy, który prowadzi do ich powstania (tamże: 19). A według niego właśnie ów model wymaga definicji, ponieważ to on jest ogniwem łączącym różnorodne pola omawianego zagadnienia. 
Design thinking, co dosyć niezręcznie oddają takie sformułowania, jak: „myślenie przez pryzmat projektu”, „myślenie jak designer” lub „myślenie projektowe”, to według Buchanana nowy paradygmat procesu twórczego, wykraczający poza sferę wzornictwa przemysłowego i wszelkiego rodzaju produkcji. Z premedytacją unikam nazwania tego procesu po prostu projektowaniem (designing). Pojęcie to odbiera mu bowiem dodatkowy i nieodzowny wymiar, jakim oprócz zwyczajnej twórczej praktyki jest „wdrożenie". Zatem - jeśli design odnosi się do charakterystyki produktu, to design thinking będzie opisem całego procesu jego powstania i zaaplikowania.

Toczy się on wedle następujących reguł:

01. idea produktu finalnego jest efektem sporu, dyskusji i wymiany argumentów, powtarzających się na każdym etapie procesu twórczego;

02. rezultat, rozwiązanie, produkt powstaja z przenikania się i respektowania czterech elementów: znaków, myśli, działań i rzeczy - oznacza to między innymi, że teoria i praktyka zostaja ze sobą sprzęgnięte, ponieważ ich rozdział jest sztucznym wytworem, który nie przystaje do doświadczenia;

03. w projekcie zostają uwzględnione trzy płaszczyzny: zamysł projektanta, wewnętrzna logika produktu (innymi słowy jego wartość użytkowa) oraz pragnienie i umiejętność człowieka, by używać produktu w codziennym życiu (tamże: 20).

Powyższe zasady mogłyby zostać rozwinięte: spór i wymiana argumentów wymagają, by w procesie uczestniczyli eksperci z różnych dziedzin, a odbiorcy byli jednocześnie współtwórcami rozwiązań, wnoszącymi swój krytyczny wkład na każdym etapie tworzenia produktu. Przenikanie się znaków, rzeczy, działań i myśli oznacza, że niemożliwe jest wyabstrahowanie od znaczenia, jakie będzie posiadał produkt, a to uzależnione jest od formy i treści, które uzyskuje w procesie „produkcji”, ten z kolei wynika z możliwość technicznych, umiejętności i wiedzy, itd. Wszystkie elementy przenikają się w każdym momencie powstawania produktu - od zaistnienia potrzeby, pomysłu, idei, przez realizowanie ich, aż po wdrożenie.

Niemożliwe jest uzmysłowienie sobie natury design thinking bez uwzględnienia zaproponowanej przez Buchanana definicji „produktu” a tym jest dla niego „każdy wytwór człowieka” (Buchanan 2010). Dzięki temu, iż produkt zostaje zdefiniowany w tak szeroki sposób, autor uzyskuje możliwość włączenia w obszar problematyki myślenia projektowego (dla którego produkt jest koniecznym punktem odniesienia) dziedzin nie tylko 
związanych stricte ze sztuką użytkową, lecz także z życiem społecznym w całej jego różnorodności. Problemy i zagadnienia związane $\mathrm{z}$ design thinking stają się tu refleksem procesów zachodzących w dynamicznie zmieniającym się świecie, a sam model pracy projektowej i kooperacja z designerami zaczynają służyć rozwiązywaniu problemów społecznych.

\section{/// Dzikie kwestie}

Powyższa, krótka charakterystyka podstaw pracy projektowej prowadzi w kierunku dwóch zasadniczych pytań: 1) Czy wykorzystanie potencjału myślenia projektowego powinno pozostać zarezerwowane jedynie dla nauk stosowanych, czy jak twierdzi Buchanan, może stać się modelem pracy w dziedzinach zupełnie niespokrewnionych ze sztuką użytkową? 2) Jakie wyzwania stoja przed badaczami dążącymi do rozwiązywania dzisiejszych problemów, biorąc pod uwagę możliwości i doświadczenia związane z obszarem design thinking?

Pierwsze zagadnienie jest o tyle trudniejsze, że dotyka sporu o granice nauki i naukowości, którego rozstrzygnięcie nie leży w mocy najtęższych umysłów. Produkt, proces, użytkownik/odbiorca, wdrożenie to pojęcia pochodzące z innego niż humanistyczny rejestru językowego. Co podkreślane jest tym wyraźniej, im większa jest stawka w grze o niezależność od rządu i sił rynkowych - choć nierzadko nie chodzi o laury dla czystej nauki, a o niezależność akademicką i pozyskiwanie funduszy publicznych. Jedną z ciekawszych, żeby nie powiedzieć fascynujących analiz wyznaczania pola naukowego na przełomie XIX i XX wieku stanowi artykuł Thomasa F. Gieryna Boundary-Work and the Demarcation of Science from Non-Science: Strains and Interests in Professional Ideologies of Scientists (1983). Bez cienia moralizatorstwa demonstruje on, w jaki sposób konteksty historyczne i gospodarcze modelowały podział na ,pure and applied sciences”. W zależności od splotu okoliczności ten sam autor to udowadniał czystość i teoretyczność nauki, to znów podkreślał jej walory praktyczne i wkład w proces postępu społecznego i technologicznego (tamże: 781, 787, 789).

Próbę pogodzenia stanowisk, przynajmniej w polu nauk społecznych, podjął Michael Burawoy, tworząc klasyfikację wiedzy w zależności od rodzaju odbiorców (Academic/Extra-Academic Audience) i użyteczności (Instrumental/Reflexive Knowlegde; 2005: 269). Na tej podstawie wyróżnił socjologię:

- tworzoną dla odbiorców akademickich: Professional (instrumentalna) i Critical (refleksyjna);

- dla pozaakademickich: Policy (instrumentalna) i Public (refleksyjna). 
W takim modelu najbliższa dynamice procesów ekonomicznych jest socjologia „polityczna”, nastawiona między innymi na efektywność, praktyczność i możliwość wykorzystania efektów badań przez klientów. $\mathrm{Na}$ drugim biegunie jest socjologia krytyczna uniezależniona od wpływów dominującego nurtu uniwersyteckiego i gry rynkowej (tamże: 276).

Bardziej interesujące od samego modelu jest jednak towarzyszące mu spostrzeżenie, że na naukę można spoglądać zarówno jak na właściwy jej „podział pracy, jak i specyficzne pole władzy” (tamże: 261). Proponując design thinking jako przykład modelu organizacji „procesu produkcji wiedzy", mam na myśli wykorzystanie go właśnie w tych dwóch perspektywach: podziału pracy w ramach samej działalności badawczej, w tym również teoretycznej (w procesie prowadzenia badań podstawowych, gdzie możliwości stosowania modelu moga zostać ograniczone do kręgów akademickich, odbiorcami sa ludzie nauki, a aspekt wdrożeniowy to dawanie impulsu do dyskusji, polemik, debat, recenzji) oraz wykraczania poza pole władzy/ wiedzy i inicjowania wspólpracy międzysektorowej.

Odpowiedzi na drugie pytanie dostarcza koncepcja tzw. wicked problems, zdefiniowanych przez Horsta Rittela w latach sześćdziesiątych XX wieku, od której amerykański profesor zaczerpnął tytuł swojego artykułu. Jest to „rodzaj problemów społecznych, które nie moga zostać dobrze zdefiniowane, gdzie informacje wprowadzają w błąd, uczestnikami są aktorzy i mocodawcy reprezentujący sprzeczne wartości, a konsekwencje dla całego systemu nie są jednoznaczne" (Buchanan 1992: 15). Stając w obliczu takiej sytuacji, dotychczasowe sposoby rozwiązywania problemów okazują się niewystarczające. Model zdominowany przez myślenie liniowe, prowadzący od specjalistycznej diagnozy przez realizację badań aż po wdrożenie, gdzie na każdym etapie pracuja inni specjaliści, a raz powzięte decyzje i zaproponowane rozwiązania nie są weryfikowane, nie przystaje do wyzwań określonych przez Rittela jako wicked, „szelmowskie”, „dzikie” w odróżnieniu od „oswojonych” problemów nauk ścisłych (Rittel, Webber 1973: 160). W sytuacji, gdy na każdym etapie realizowania projektu pojawiaja się nowe dane, nowe fakty i nowi aktorzy, całkowicie bezzasadne, żeby nie powiedzieć bezsensowne, jest opieranie się jedynie na wstępnej idei, diagnozie, propozycji lub zamówieniu, niemodyfikowanych w toku pracy.

Giddens trafnie zauważyl, że systemy eksperckie i relacje społeczne charakteryzuje oderwanie od kontekstu lokalnego (disembedding; 2006: 25 -26), ale ich funkcjonowanie jest możliwe dzięki wyważeniu kategorii zaufania i ryzyka (tamże: 184). Nie mógł jednak przewidzieć wynikajacych stąd praktycznych konsekwencji, zwielokrotnionych ze względu na 
rozpowszechnienie się internetu - źródła wiedzy oraz środka przekazu i komunikacji o skali daleko przewyższającej możliwości, jakie przynosił on w czasach, gdy Giddens pisał Nowoczesność i to żsamość. Zaufanie wymaga przynajmniej pobieżnej wiedzy o funkcjonowaniu systemów abstrakcyjnych, w których skład wchodzą również systemy eksperckie (tamże: 27-28). Obecność nowych technologii, o coraz wyższym stopniu skomplikowania, wyklucza możliwość poznania przez wszystkich aktorów społecznych zasad ich działania i, na pierwszy rzut oka, odcina jednostki od możliwości ich kontrolowania, nie wspominając o wpływie na ich funkcjonowanie i zmianę ${ }^{1}$. Specjalistą można zostać jedynie w bardzo wąskiej dziedzinie wiedzy (tamże: 170). Kooperacja lub interdyscyplinarność rozumiana jako współpraca ekspertów z różnych dziedzin staje się zatem zjawiskiem nie tyle pożądanym, ile nieodzownym.

Co więcej internet, dynamika społeczna i migracje, a jednocześnie obowiązki międzynarodowej współpracy, nakładanej na badaczy pragnących brać udział w poważnych przedsięwzięciach naukowych, wymagają poszukiwania transkulturowego porozumienia. Wielokulturowość - co trafnie zauważyła Aldona Jawłowska, odwołując się do teorii Wolfganga Welscha - nie może sprostać wyzwaniom pojawiajacym się w XXI wieku. „Wzajemne powiązania i przenikanie się zjawisk należących do różnych sfer rzeczywistości i układów kultury" (Jawłowska, oprac. 2006: 19) nakazuja zastanowić się głębiej nad dotychczasowym porządkiem społecznym i granicami pól opisanych przez Pierre’a Bourdieu (1990: 148-149), których przekraczanie leży w interesie społeczeństwa. Również w ramach jednej dyscypliny powinien następować przepływ wiedzy, umożliwiający tworzenie nauki „kosmopolitycznej”, a nie narodowej (Beck 2005: 340). Ta ostatnia może wręcz ograniczać perspektywę, stając się gwarantem istniejącego porządku. A przecież nauka powinna wspierać procesy przemiany - nie legitymować status quo, ale mobilizować do włączania jak najszerszych obszarów w rejony wiedzy i uświadamiać jednostkom działanie systemów, których są aktorami (por.: Touraine 2010: 299). Często bywa jednak tak, że badacze ulegaja złudzeniu „samoprzejrzystości” przedmiotu swoich badań (por.: Vattimo 2006: 18), zapominając, że rzeczywistość zapośredniczona przez media lub będąca efektem dominującego dyskursu wprowadza w błąd. Naukowiec - by sparafrazować słowa Touraine’a - „nie powinien wierzyć społeczeństwu" (Touraine 2010: 291). Docieranie do podstaw

\footnotetext{
${ }^{1}$ Ciekawym przykładem polemiki z „ujarzmiającymi” cechami systemów eksperckich jest artykuł Pawła Tomanka Ujarzmienie çy legitymizacia? Normalizacyjne aspekty dyskursów eksperckich, „Studia Socjologiczne", 1 (204)/2012, s. 111-129.
} 
tworzenia - prawa, stosunków społecznych, wiedzy - wymaga bycia „naocznym świadkiem”. Gdzie leży granica tego udziału, może być przedmiotem dyskusji, ale badacz nigdy nie powinien dać się zwieść tyranii grupy, która broni pola nauki nie z miłości do wiedzy, ale swojego interesu Gieryn, na co powoływałam się wyżej, doskonale to zanalizował.

Kastalia Hessego, czyli wyimaginowane miasto spokojnej egzystencji intelektualistów, pozbawionych trosk świata zewnętrznego i prowadzących wysublimowana grę szklanych paciorków, dla wielu stanowi wzór działalności akademickiej. Ale uniwersytet nie jest zawieszony w próżni, to miejsce spotkania studentów i profesorów; potrzeb rynkowych i potrzeby czerpania wiedzy. Wobec nikłego odsetka osób kontynuujących karierę akademicką (Raport I: 46) moralnie wątpliwe jest uznawanie całej rzeszy studentów z dyplomem za straconych, ponieważ „powrócili” oni do gry rynkowej.

Przepływ wiedzy między podmiotami działającymi dla zysku a uczelnianymi w naukach ścisłych odbywa się naturalnie, ponieważ nowa technologia wymaga specjalistów. Jednak współczesna gospodarka to nie tylko technologia. Humaniści zbyt łatwo godzą się na to, by między nimi a sektorem usług nie występowała żadna wymiana (por. tamże: 52).

Modele organizacji współpracy międzysektorowej i międzyuczelnianej, które sprawdziły się na polu ekonomii, zarządzania i w jakiejś mierze nauk ścisłych, moga dostarczyć gotowej formuły takiego współdziałania. Nie postuluję bezrefleksyjnego korzystania z wzorca, ale jego krytyczną analizę. Potrzeba zysku, napędzająca rynek podobnych modeli, nie powinna odstręczać badaczy od przyjrzenia się bliżej ich zasadom. Tym bardziej że właśnie potrzeba zysku sprawia, iż szybciej zostają one dostosowane do kontekstu, w jakim są wykorzystywane. Nie mówiąc już o tym, że uwzględnianie czynnika finansowego pozbawiłoby obszar nauki elementu marnotrawstwa, towarzyszącego częstokroć pogoni za tytułami, zdobywanymi dzięki bezpiecznej, bo nieobciążonej ryzykiem niepowodzenia, działalności badawczej (por. Kosmulski 2012).

Zrozumienie potrzeby interdyscyplinarności jako jednego z postulatów nowoczesnego sposobu myślenia prowadzi w odpowiednim kierunku. Jednak, jak zaznaczyłam wyżej, taka jej forma, jaka dziś funkcjonuje w polu naukowym, nie jest wystarczająca, nie mówiąc już o tym, iż nie powinna być jedynym czynnikiem branym pod uwagę w podejmowaniu społecznych wyzwań. Analiza procesu wytwórczego i projektowania (produktów i usług), jako analogia dla rozwiązywania problemów społecznych, kulturowych i „transkulturowych”, może przynieść badaczom gotowe narzędzia, 
które wystarczy przystosować do potrzeb badań naukowych, sięgających o wiele dalej niż socjologiczne interwencje (por. Touraine 2000: 900-918).

Opis, diagnoza i uszeregowanie procesów zachodzących w ramach danego problemu zostają tu bowiem uzupełnione myślą o wdrożeniu rozwiązania, nad którym również czuwa i które współopracowuje badacz. Dzięki temu ponosi odpowiedzialność za swoje „diagnozy i rekomendacje”, często traktowane jako jego jedyny wkład w szeroko rozumiana politykę społeczna. I nie chodzi o obarczenie naukowca rola ,kozła ofiarnego” w obliczu porażki. Współpraca przy konstruowaniu rozwiązań to konieczność w zmierzeniu się z problemami nauk humanistycznych i społecznych, które, na co powoływałam się wyżej, są ,nieoswojone” i dynamiczne. I kto jak kto, ale socjolog, znający dynamikę zmian społecznych, nie powinien tej odpowiedzialności unikać.

Design thinking, jako podstawa dla projektowania różnego typu rozwiązań tworzonych z myślą o społeczeństwie, dostarcza, pośród wielu innych, także tej wiedzy, której brakowało modernistom projektującym doskonale urządzone przestrzenie, gdzie życie społeczne, wbrew oczekiwaniom i stosowanej przez architektów logice - zamierało. Jednym z najmniej chlubnych przykładów była idealnie zaplanowana dzielnica Pruitt-Igoe w St. Louis w stanie Missouri, zburzona po tym, jak system okazał sie bezbronny wobec szerzących się tam patologii (Ready 2011). Design thinking wnosi bowiem nowe rozumienie eksperckości - staje się ona kategoria płynna i inkluzywna. Specjalistą może okazać się każdy dysponent kapitału, jakim w ostatecznym rozrachunku jest nawet doświadczenie potoczne, czasem bardziej wartościowe niż udokumentowana wiedza. Dlatego wspólnikiem badacza bądź twórcy staje się użytkownik przestrzeni lub produktu (Goličnik Marušić, Nikšič, Coirier, 2010: 54) i to on jest głównym uczestnikiem procesu, zaś takie opozycje jak: nadawca-odbiorca, twórcaodtwórca zostają zniesione. W eksperckim roztargnieniu często zapomina się o tym, dla kogo wprowadzane są zmiany. Tak jak to się stało podczas remontu katowickiego dworca, który tylko dzięki inicjatywie Pawła Nowaka (informatyka) - pomysłodawcy World Usability Day Silesia - został oznaczony wskazówkami dla podróżnych (Nowak 2012).

Dlatego próbując zaadaptować model procesu projektowego do działalności naukowo-badawczej, należy uwzględnić przede wszystkim zredefiniowanie relacji między „twórcami i odbiorcami” działań. Nie wspominając o tym, iż czasem wystarczy zwyczajna zamiana miejsc i przyjęcie perspektywy drugiej strony. 


\section{/// Problemy udomowione}

Opis poniższych kategorii będzie jedynie wstępem do dalszych analiz, próbą uwzględnienia myśli Buchanana w pracy naukowo-badawczej. Dlatego też traktować je należy jako pewne typy idealne, sytuacje, jakie mogłyby zaistnieć, gdyby proces projektowy zawsze spełniał standardy przywołane przez autora Wicked problems..., a badacze mogli uwzględniać te standardy w każdych okolicznościach.

\section{Interdyscyplinarnosí}

W naukach humanistycznych utarło się rozumieć interdyscyplinarność jako współpracę specjalistów z różnych dziedzin lub wszechstronność pojedynczej jednostki i jej gotowość do poszerzania własnej wiedzy (Kloch 2007). Design thinking uczy natomiast, by, po pierwsze, również „przedmiot badany", odbiorcę zmian, grupę, której dotyczy rozwiązanie - czyli jednym słowem użytkownika produktu (w rozumieniu Buchanana) - włączyć do procesu badawczego, ponieważ to on ostatecznie zweryfikuje funkcjonalność rozwiązań. Po drugie, uczestnikami procesu powinni się stać również wszyscy ci, od których decyzji, działań i zasobów zależy wprowadzenie rozwiązania.

W niektórych dziedzinach, jak choćby w analizie literackiej, takie podejście byłoby absurdem. Trudno wyobrazić sobie, by badacz, pisząc o dziełach Prousta, zaprosił do współpracy przedmiot swoich dociekań. Tu odbiorcami pozostaja przedstawiciele świata nauki. Ale bez stosowania przynajmniej minimum interdyscyplinarności zdefiniowanej przez Klocha nawet najczystszej humanistyce grozi obniżenie standardów. Recenzowanie (krytyczne!) prac, zanim trafią do druku (to znaczy w takim momencie, gdy uwagi mają wpływ na ostateczną konstrukcję i zawartość tekstu) przez osoby niezwiązane z własną dziedzina, nie tylko przynosi pozytywne efekty, lecz również chroni przed kompromitacja. Można nie zgadzać się z upraszczającymi wnioskami Alana Sokala (2004), dotyczącymi zapożyczeń z nauk ścisłych, jakimi błędnie posługują się przedstawiciele dziedzin humanistycznych, ale odmawianie mu prawa do obrony własnego pola i obowiązujących w nim norm naukowości jest nadużyciem, szczególnie gdy jednocześnie w obronę wzięte są normy obowiązujące we własnym polu (por. Gajewski 2005: 132).

W dziedzinie badań społecznych propozycja Buchanana mogłaby stanowić wartościowy punkt odniesienia. Praca badawcza koncentruje się tu na kontakcie z „obiektem badanym”. Jednak zazwyczaj jego zadania zostają ograniczone do udzielania odpowiedzi, bądź dyskusji pod okiem 
przygotowanego moderatora. Po tym wstępnym etapie to sam badacz podejmuje wysiłek sformułowania wniosków, podsumowań, rekomendacji, które ostatecznie trafiają do wykonawców. A tam, traktowane wybiórczo i bez należytej uwagi, stają się przedmiotem i narzędziem manipulacji, dezawuując tym samym wiedzę „użyteczną” (Beck 2005: 337; Polak 2012: 134). Uczestnictwo w całym procesie - zarówno badacza, badanych, jak i wykonawców rozwiązań - jest odpowiedzią na powyższe problemy. Osobista konfrontacja byłaby tu ideałem, biorąc pod uwage ignorowanie słowa pisanego, jego podatność na manipulację i upraszczanie wypowiedzi przez media.

\section{Relacje eksperckie}

Jednocześnie ciagłe apele o interdyscyplinarność banalizuja to pojęcie, zamiast uszczegółowić, o co w nim faktycznie chodzi. Rozszerzanie zakresu kooperacji ekspertów z różnych dziedzin oraz włączanie decydentów różnych szczebli administracji i przemysłu to tylko jeden z jej aspektów stosowany bez specjalnego namysłu może prowadzić do fragmentaryzacji badań i polifonii, która staje się przelewaniem z pustego w próżne. Dlatego interdyscyplinarności powinna towarzyszyć zmiana modelu współpracy, wciąż obciążonej zasadami hierarchii, biernością i brakiem innowacyjnych pomysłów lub (co jeszcze gorsze, bo utrwala ten uczelniany modum operandi) powstrzymywaniem aktywnych badaczy przez bariery środowiska pracy, nieprzyjaznego zmianom (Raport I: 52).

Opisany wyżej przykład dzielnicy Pruitt-Igoe dobitnie świadczy o tym, że ekspertom nierzadko również brakuje pokory i przekonani o własnej słuszności, intuicji i guście, doprowadzają do katastrof. Ze względu na obciążenie konkretnym habitusem nie doceniają wiedzy spoza reprezentowanej przez nich narracji, a jeśli współpracują z użytkownikami i pracownikami niższego szczebla, to tylko w tym celu, by zebrać odpowiedni materiał i samodzielnie podjąć ostateczne, arbitralne decyzje.

W zgodzie z design thinking każdy uczestnik procesu rozwiązywania problemu jest ekspertem, a jego wiedza, o ile wnosi istotny wkład w rozwiązanie problemu (teoretycznego lub praktycznego), powinna być traktowana na równi z innymi, niezależnie od statusu, doświadczenia i stażu specjalisty zabierającego głos. Dlatego pracę warto opierać na relacjach partnerskich, a nie tytularnej hierarchii. Nie mówiąc już o tym, że istotne jest nawiązywanie relacji, zdobywanie nowych kontaktów i w ten sposób aranżowanie współpracy międzyuczelnianej i międzysektorowej. 


\section{Postawa wobec konfliktu}

Zmiana hierarchii $\mathrm{w}$ relacje partnerskie jest trudna ze względu na niechęć badaczy do prowadzenia konstruktywnych sporów. Zwolennicy odmiennych metodologii traktują siebie nawzajem jak wrogów i nie potrafia „aktywnie słuchać” ${ }^{2}$ argumentacji drugiej strony. W najlepszym razie dochodzą do kompromisu, co oznacza, iż albo jedna, albo obie strony poddały się i zrezygnowały z części swoich przekonań, by powołać do życia badawczą hybrydę. To nie jest sytuacja typowa jedynie dla środowiska naukowego. Według Chantal Mouffe dążenie do konsensu, które właściwie marginalizuje pluralistyczne i niejednorodne punkty widzenia, na rzecz uśrednionych (co nie oznacza, iż reprezentowanych przez większość, raczej akceptowalnych przez ogól) to cecha typowa dla demokracji in toto (Mouffe 2005: 67). Dlatego Buchanan dąży do tego, by z design thinking czerpać wiedzę o umiejętności prowadzenia sporów, argumentacji, twórczej wymianie poglądów. Co w efekcie prowadzi nie tyle do powszechnej zgody, ile do głębszej analizy, uwzględniania danych, których we własnej argumentacji nie brano wcześniej pod uwagę i ostatecznie stworzenia rozwiązania, które ma większą szansę na bezkonfliktową realizację. Takie podejście zakłada również zgodę na „protokół rozbieżności”, czyli możliwość zachowania własnego zdania bez obawy o usytuowanie się w relacji wrogości i agresji.

Nauka tylko wówczas ma szansę zaistnieć na arenie międzynarodowej, gdy jej odkrycia są znaczące, ale droga prowadząca do nich zazwyczaj naznaczona jest ryzykiem niepowodzenia. Konflikt przyzwyczaja do sytuacji, gdy racja niekoniecznie jest po jednej stronie, oswaja z możliwościa porażki.

\section{Oddriatywanie}

Design thinking pozwala spojrzeć na społeczeństwo nie jak na konglomerat grup zróżnicowanych ze względu na swoje cechy demograficzne, ale jak na różne typy „użytkowników” planowanych rozwiązań. Aby ich zidentyfikować, potrzeba o wiele głębszej diagnozy niż prześledzenie statystycznych danych. Jest to proces długotrwały, ponieważ już na poziomie wstępnego rozpoznania należy zastosować kilka różnych narzędzi, pozwalających zaprosić do współpracy rzeczywistych odbiorców działań, a nie demograficzny przekrój danej społeczności - ten powinien pełnić rolę uzupełniająca, stwarzając ramy dla wyboru jednostek według opisanych wyżej kryteriów. W obszarze biznesu takie działanie uzasadniaja warunki zysku: produkt

\footnotetext{
${ }^{2}$ Jedna z technik stosowanych podczas mediacji, polegająca na uważnym słuchaniu uczestników spotkania mediacyjnego, parafrazowaniu ich wypowiedzi, zadawaniu pytań pomocniczych.
} 
musi trafić w gust i potrzebę jego rzeczywistych odbiorców, by przynieść zysk. W praktyce badawczej, szczególnie nauk społecznych, rentowność (rozumiana jako racjonalne wykorzystanie finansów publicznych) nie odgrywa roli, ponieważ zysk uczelni z realizacji badań często nie zależy od ich jakości i możliwości wykorzystania przez odbiorców (czy będą to inni naukowcy, czy klienci ze sfery publicznej). Według raportu „Diagnoza stanu szkolnictwa wyższego w Polsce" algorytm przyznawania środków uczelniom publicznym opiera się między innymi na parametrach określających liczbę projektów badawczych i liczbę studentów. Wzrostowi wartości tych wskaźników odpowiada wzrost finansowania niezależnie od jakościowej, merytorycznej oceny działalności placówki naukowej (2009: 59, 68).

Dlatego przepływ środków między instytucjami publicznymi (finansującymi) a placówkami badawczymi, wbrew powszechnej opinii, odbywa się swobodnie $-\mathrm{z}$ dużą dozą naiwności i wiary w słuszność tego procederu, nawet jeśli efekty zleconych badań i pracy naukowej nigdy nie ujrzą światła dziennego. Panująca tu logika jest prosta: kumulacja wiedzy ma służyć innym naukowcom, którzy z kolei na tej podstawie stworzą kolejne teorie dostępne jedynie innym naukowcom i tak dalej... Nie byłoby w tym może nic niepokojącego - w końcu wzrost kapitału symbolicznego jest zyskiem niemierzalnym w kategoriach rynkowych - gdyby nie fakt, iż polskie uczelnie działaja na zasadzie „chowu wsobnego”. Praktyczny brak mobilności geograficznej, nie mówiąc o międzysektorowej, i kontynuacja kolejnych stopni kariery naukowej w macierzystej uczelni (tamże: 52-53), powodują zamykanie się w obrębie nie tyle nawet jednego pola naukowego i jednej dyscypliny, ale wręcz w ramach jednego wycinka rzeczywistości: metodologicznej, teoretycznej i empirycznej. Studenci studiów licencjackich lub magisterskich, kontynuujący naukę na innym wydziale, ale w ramach tej samej dziedziny, moga mieć poczucie schizofrenii wynikającej z zarażenia dwiema zupełnie innymi ideami nauki. I znów wydaje się, że to poszerzanie perspektyw powinno być jedynie owocne - byłoby, gdyby nie fakt, iż przyjęcie każdego z modeli wiąże się z degradacja poprzedniego. Zamiast twórczego włączenia do własnego repertuaru, kolejni akademicy wolą traktować go z ironicznym dystansem (por. Burawoy 2005: 277).

W podmiotach skoncentrowanych na kapitale, jak i w sektorze organizacji pozarządowych, dla których stałe subwencje zostały zastapione dotowaniem konkretnych projektów, nacisk jest położony na promocję. Reklama, „dźwignia handlu”, równie dobrze mogłaby się stać dźwignią nauki, gdyby mentalność nie kazała naukowcom tak pilnie strzec wyników swoich badań - których wartość dla życia społecznego jest nie tylko 
nieoceniona, ale również niedoceniona. Zapewne ogromne znaczenie ma odbieranie aspektu wdrożeniowego projektów badawczych jako zamachu na czystość nauk teoretycznych, tak jakby pierwiastek refleksji był zabijany przez obowiązek przewidywania jej praktycznych zastosowań. „Impact”, czyli w międzynarodowych konkursach grantowych jeden z najwyżej ocenianych elementów projektu badawczego, nie musi jednak oznaczać bezpośredniego wykorzystania wniosków z badań w praktyce produkcyjnej lub w polityce społecznej. Wpływ to również oddziaływanie na innych, „zarażanie" ich swoimi ideami, postawami i rozwiązaniami. Niestety polska nauka obciążona jest swoistym lękiem przed wpływem, przed wykorzystaniem badań, a przede wszystkim przed możliwością, i tu już w istocie komentarz jest zbędny, zainspirowania swoją teorią innych naukowców.

\section{Struktura procesu}

Udrażnianie komunikacji między administracją publiczną, przedsiębiorcami, nauką i odbiorcami w odniesieniu do praktyki staje się pustosłowiem. Nadanie badaniom i analizom walorów chociażby względnej użyteczności musi powodować rezygnację z obrony własnego pola, którego granicę wyznaczaja niezrozumiały, specjalistyczny język, konkretne dyspozycje (Bourdieu 2005: 216) oraz niechęć wobec zmian i akceptacji innego sposobu myślenia niż własny. Model design thinking stwarza możliwość przekroczenia tych barier dzięki pracy zespołowej trwającej na każdym etapie działań: od podjęcia wyzwania przez poszukiwanie rozwiązań po wdrożenie jednego z nich. Myślenie liniowe zastapione zostaje tu czymś na kształt spirali: na każdym etapie włączani są eksperci i specjaliści, a w dyskusjach nad efektami ich działań biorą udział odbiorcy modyfikujący i współtworzący rozwiązania aż po takie, które dadzą nadzieję na spełnienie przyjętych przez zespół parametrów (np. funkcjonalności). Jednocześnie uwzględniane są dostępne zasoby, a uczestnicy dbają o to, aby przepływ informacji następował we wszystkich kierunkach. Nie ma tu miejsca na nadawcę i odbiorcę. Organizują się oni wokól pracy nad daną kwestią i to ona, a nie przekonania i wartości, wyznacza obszar współpracy. $\mathrm{Na}-$ miastkę takiego sposobu myślenia można było zaobserwować podczas protestów społecznych, które przetoczyły się przez Europę w związku z kontrowersyjnym Anti-Counterfeiting Trade Agreement (ACTA), gdy ogniwem scalającym różne grupy, zabierające głos w tej sprawie, nie była wspólnota poglądów, ale wspólny problem.

Aby jednak doszło do współpracy zespołowej, naukowcy muszą wykazać się większą mobilnością, co w polskich warunkach jest utrudnione ze względu na niskie wynagrodzenia i dosyć wysoki średni wiek nauczycieli 
akademickich (Raport I: 44, 53). Mobilność jest zatem ograniczona nie zawsze z powodów mentalnych. Tym bardziej że w dotacjach i grantach narodowych rzadko przewiduje się finansowanie kosztów związanych z migracją członka rodziny badacza.

Zdobywanie dodatkowych środków na pracę badawczą w ramach zespołu stworzonego poza macierzystą uczelnią wiąże się również z pokonywaniem barier administracyjnych (Raport I: 52), które nie tylko w Polsce uznawane sa za największe przeszkody w procesie pozytywnych zmian społecznych (Raport II: 54). Odbija się to dotkliwie na aktywnych, ambitnych badaczach, którzy nie uzyskuja żadnego wsparcia, o ile sami nie zajmą się całą organizacja procesu projektowego - w innych krajach OECD na porządku dziennym jest zatrudnianie specjalistów (Raport I: 53). W Polsce badacz zamiast korzystać na współpracy z nimi i koncentrować się na pracy naukowej, sam obciążony jest zadaniami administracyjnymi.

\section{/// Oswajanie badaczy}

Buchanan opublikował swój esej w 1992 roku. Modele pokrewne design thinking już wówczas odgrywały dużą rolę w organizacji systemów biznesowych, w budowaniu relacji między producentem, jego produktem i klientem oraz $\mathrm{w}$ usprawnianiu komunikacji w przedsiębiorstwach. I odgrywają nadal (Stewart 2011: 515).

To w tamtym czasie również piśmiennictwo naukowe zaczęło zapełniać się propozycjami modeli wypracowanych na podstawie design thinking i pokrewnych mu rodzajów myślenia i działania. Na całym świecie powstawały instytuty i centra współpracy ${ }^{3}$ między jednostkami twórczymi a naukowymi, w tym założone przez samego Buchanana Interaction Design Association promujące jego metodę: Interaction Design $(I x D)$ za pośrednictwem grup lokalnych rozsianych od Stanów Zjednoczonych po Indie. Kulminacją powyższego trendu było wydanie przez renomowane międzynarodowe pismo naukowe „Design Studies” w 2011 roku całego numeru dedykowanego design thinking, gdzie większość miejsca poświęcono społecznym korzyściom związanym z jego stosowaniem.

\footnotetext{
${ }^{3} \mathrm{~W}$ ramach „Design Innovation \& Exchange Programme Berlin-Wielkopolska 2011-2012” 1-2 grudnia 2011 roku odbyły się w Poznaniu warsztaty oparte na metodzie design thinking. Opracowywany przez uczestników problem dotyczył co prawda sfery biznesu, jednak do współpracy zostali również zaproszeni przedstawiciele nauk humanistycznych. Nic nie stoi zatem na przeszkodzie, by podobna kooperacja towarzyszyła rozwiązywaniu problemów społecznych: http://berlin-wielkopolska.eu/pl/modul/workshop_1_/ (dostęp: wrzesień 2012).
} 
Pierwsze spotkanie z tym tematem wciąż rodzi jednak reakcję obronna na wzór tej, którą Buchanan przypisał przedstawicielom i teoretykom sztuk pięknych $\mathrm{w}$ ich zetknięciu z kategorią design. Skojarzenia z wzornictwem przemysłowym, produkcja, produktem i wreszcie modą dewaluują model pracy projektowej, który w oczach naukowców, skoncentrowanych na „poważnych" problemach, może prezentować się jako błahy i nieprzystający do reprezentowanego przez nich modelu nauki - wyzbytego pierwiastka bezpośredniej użyteczności. Apele o interdyscyplinarność, otwarcie nauki na współpracę z przemysłem i komercjalizację wyników badań, w celu budowania podstaw rozwoju społecznego, szczególnie w naukach społecznych i humanistycznych nie spotykaja się ze znaczącym odzewem mimo deklarowanych chęci (zob. Chmielewski, Dudzikowa, Grobler 2012). Mało jest takich wypowiedzi jak ta profesora Adama Płaźnika, w której nie deprecjonuje on potrzeby zmiany modelu pracy naukowej, ale rzetelnie wskazuje na przeszkody, jakie uniemożliwiaja polskim naukowcom wkroczenie do międzynarodowego obiegu na równych szansach (Płaźnik 2012). O wiele częściej uwidacznia się tęsknota za rajem utraconym, za niezależnością nauki, równie prawdziwa jak Owidiuszowy Złoty Wiek.

Tymczasem design thinking wstępuje w obszar badań nad procesami społecznymi, a współpraca między designerami, przedsiębiorcami i ludźmi nauki staje się pożądanym i wymaganym warunkiem prowadzenia międzynarodowych, innowacyjnych badań we wszystkich dyscyplinach wiedzy ${ }^{4}$. Dlatego brak zainteresowania humanistów nowymi modelami myślenia przy podejmowaniu społecznych wyzwań jest dojmujący. Co jest szczególnie zagadkowe, biorąc pod uwagę obserwacje Clifforda Geertza. Pisząc o „gatunkach zmąconych”, zauważa on wśród badaczy społecznych potrzebę odwołań do twórczości literackiej - tak jakby przeczucie wskazywało im, że odpowiedzi na wiele pytań dostarczają narracje pochodzące spoza wąsko rozumianych dziedzin nauki (Geertz 2005: 29-30). Designerzy i szkoły skoncentrowane na projektowaniu coraz chętniej korzystaja ze specjalistycznej wiedzy socjologów, psychologów i humanistów. Strelka Institute of Media, Architecture and Design w Moskwie, założony

\footnotetext{
${ }^{4}$ Szczególnie istotne wydają się tu wytyczne realizowania projektów badawczych pod auspicjami Komisji Europejskiej w ramach Siódmego Programu Ramowego. Śledząc call for proposals, można odnieść wrażenie, że współczesne myślenie o nauce powinno całkowicie przekraczać bariery i granice wyznaczone przez obszar dotychczasowych działań instytucji badawczych i uwzględniać współpracę z podmiotami, które nie wchodzą w zbiór jednostek określanych jako „naukowe”; dotyczy to w równym stopniu dziedzin humanistycznych i społecznych, jak ścisłych. Zob. m.in. opis głównych wytycznych dla programu Ideas:

http://ec.europa.eu/research/participants/portal/download?docId=30036 (dostęp: wrzesień 2012).
} 
z inicjatywy Rema Koolhasa, czy School of Form w Poznaniu, stworzona przy wsparciu Lidewij Edelkoort, chlubią się bliską współpracą z przedstawicielami dziedzin humanistycznych. Przepływ wiedzy w odwrotnym kierunku wciąż pozostaje marzeniem kilku zapaleńców.

Raporty i artykuły jako ostateczne produkty pracy badawczej nieustannie traktowane sa przez humanistów $z$ wielkim namaszczeniem, tak jakby magia słowa pisanego wystarczyła, by tchnąc życie w proces społecznej zmiany. A przecież specyfika wyzwań zogniskowanych na społeczeństwie powinna wpływać na zacieranie granic między obszarami nauki, biznesu, sektorów twórczych i polityki społecznej. Jak pisze Burawoy, naukowcy jako „społeczność zbyt łatwo idą na wojnę z «innymi», ślepi na niezbędną współzależność między różnorodnymi dziedzinami wiedzy” (2005: 277).

Badacz jako strażnik metodologii i rzetelności badań nie musi obserwować procesu zza szklanej szyby. Profesjonalizm, asertywność i umiejętność prowadzenia sporu, a nie dystans, powinny mu zapewnić charyzmę. Tym bardziej że jego dyspozycje są czasem niezbędne, by uwzględnić czynniki i dane pojawiające się w trakcie procesu, a nie jedynie na jego początku (opracowanie narzędzi) lub domniemanym końcu (opracowanie wyników). Rozwiązaniem wielu problemów sa proste pomysły, a te nie powstana, gdy jedynym punktem styku między ich możliwym wykonawcą (np. designerem) a badaczem będzie profesjonalny, wyczerpujący i ignorowany przez środowiska pozanaukowe - raport. Czasem konieczne jest bowiem, by między designerem a badaczem doszło do konfrontacji, a nawet kłótni, podczas których wnioski zawarte w raporcie trafią mimochodem na podatny grunt. Przedstawiciele obszarów kreatywnych już korzystają z wiedzy naukowej spoza własnej dziedziny. Pora, by humaniści przestali kojarzyć ich jedynie z „żółtymi karteczkami” i „burzami mózgów” (Lipiec 2012), a spojrzeli na projektowanie jak na skomplikowany proces i wyciagnęli użyteczne wnioski.

\section{Bibliografia:}

/// Agamben G. 2010. Nagośc, tłum. K. Żaboklicki, Wydawnictwo WAB, Warszawa.

/// Beck U. 2005. How not to become a museum piece?, "The British Journal of Sociology" 2005, nr 56 (3), s. 335-343.

/// Bourdieu P. 2005. Dystynkicja. Społeczna krytyka władzy sadzenia, tłum. P. Biłos, Wydawnictwo Naukowe Scholar, Warszawa. 
/// Bourdieu P. 1990. In Other Words. Essays Towards a Reflexive Sociology, tłum. M. Adamson, Stanford University Press, Stanford.

/// Buchanan R. 2010. What and where is interaction design? http:// designforservice.wordpress.com/buchanan-keynote-scad/; dostęp: 20.09.2012.

/// Buchanan R. 1992. Wicked Problems in Design Tbinking, "Design Issues" 1992, nr 8 (2), s. 5-21.

/// Burawoy M. 2005. Forpublic sociology, "The British Journal of Sociology" 2005, nr 56 (2), s. 259-294.

// / Chmielewski A., Dudzikowa M., Grobler A., red. 2012. Interdyscyplinarnie o interdyscyplinarności: międyy idea a praktyka, Oficyna Wydawnicza „Impuls”, Kraków.

/// Churchman C.W. 1967. Wicked Problems, "Management Science" 1967, nr 14 (4), s. B141-B142.

// / Gajewski K. 2005. Nie czas na żarty, panie Sokal!, „,Teksty Drugie” 2005, nr 94 (4), s. 121-132.

/// Geertz C. 2005. Wiedza lokalna. Dalsze eseje z. zakresu antropologii interpretatywnej, tłum. D. Wolska, Wydawnictwo Uniwersytetu Jagiellońskiego, Kraków.

/// Giddens A. 2006. Nowoczesność $i$ tożsamość, tłum. A. Szulżycka, Wydawnictwo Naukowe PWN, Warszawa.

/// Gieryn T.F. 1983, Boundary-work and the demarcation of science from non-science: strains and interests in professional ideologies of scientists, "American Sociological Review" 1983, nr 48, s. 781-795.

/// Goličnik Marušić B., Nikšič M., Coirier L., red. 2010. Human Cities: Celebrating Public Space, Stichting Kunstboek, Oostkamp.

/// Jawłowska A., oprac. 2006. Interdyscyplinarnosí - postulat teoretyczny i doświadczenie, „Societas/Communitas” 2006, nr 1 (1), s. 5-20.

/// Kloch Z. 2007. Interdyscyplinarność w naukach bumanistycznych, tekst wygłoszony na seminarium Wydziału I Nauk Społecznych PAN i Instytutu Filozofii i Socjologii PAN: „Interdyscyplinarność w naukach społecznych i humanistycznych - możliwości i ograniczenia”, Warszawa, 21 XI 2007.

/// Kosmulski M. 2012. Vabank, „Forum Akademickie” 2012, nr 6.http:// forumakademickie.pl/fa/2012/06/vabank/; dostęp: 30.12.2012. 
/// Lipiec M. 2012. Design thinking $i$ çy coś z tego wynika? http://uxdesign. pl/design-thinking-i-czy-cos-z-tego-wynika; dostęp: 30.12.2012.

/// Mouffe Ch. 2005. Paradoks demokracji, tłum. W. Jach, M. Kamińska, A. Orzechowski, Wydawnictwo Naukowe Dolnośląskiej Szkoły Wyższej Edukacji TWP, Wrocław.

/// Nowak P. 2012. Użytecæna inicjatywa. http://tedxrawariver.pl/zobaczcieprezentacje-z-tedxrawariver-2012/\#more-572; dostęp: 30.12.2012.

/// Polak P. 2012. Socjologia i socjolodzy w zglobalizowanym świecie. Kilka unvag o socjologiach narodonych, „Studia Socjologiczne” 2012, nr 3 (206), s. 123-143.

/// Raport I: Diagnoza stanu szkolnictwa wyższego w Polsce, Ernst\&Young Business Advisory i Instytut Badań nad Gospodarka Rynkowa, listopad 2010. http://ptbk.mol.uj.edu.pl/download/aktualnosci/akt.diagnoza.pdf; dostęp: 30.12.2012.

// / Raport II: Promoting Dynamic Reform Across Europe's Public Administrations: Using European Social Fund Effectively, Ministerstwo Rozwoju Regionalnego 2012.

/// Ready A. 2011. Dtugi cień postmodernizmu, „Dwutygodnik” 2011, nr 70. http://www.dwutygodnik.com/artykul/2882; dostęp: 20.09.2012.

/// Rittel H., Webber M. 1973. Dilemmas in a General Theory of Planning, "Policy Sciences" 1973, nr 4, s. 155-169.

/// Sokal A., Bricmont J. 2004. Modne bzdury: o nadusymaniu pojeć z. zakresu nauk ścistych przezpostmodernistycznych intelektualistón, tłum. P. Amsterdamski, Prószyński i S-ka, Warszawa.

/// Stewart S.C. 2011. Interpreting Design Thinking (Editorial), "Design Studies. The International Journal for Design Research in Engineering, Architecture, Products and Systems" 2011, nr 32 (6), s. 515-520.

/// Tomanek P. 2012. Ujarzmienie cay legitymizacja? Normalizacyjne aspekty dyskursów eksperckich, „Studia Socjologiczne” 2012, nr 1 (204), s. 111-129.

/// Touraine A. 2000. A Method for Studying Social Actors, "Journal of World Systems Research" 2000, vol. 6. nr 3, s. 900-918. http://jwsr.ucr.edu/ archive/vol6/number3/pdf/jwsr-v6n3-touraine.pdf; dostęp: 20.09.2012.

/// Touraine A. 2010. O socjologii, tłum. M. Warchala, Wydawnictwo Naukowe PWN, Warszawa. 
/// Vattimo G. 2006. Społeczeństwo præejrzyste, tłum. M. Kamińska, Wydawnictwo Naukowe Dolnośląskiej Szkoły Wyższej Edukacji TWP, Wrocław. Wytyczne programu Ideas: http://ec.europa.eu/research/participants/portal/download?docId=30036; dostęp: 20.09.2012.

\section{/// Abstrakt}

Design thinking to $\mathrm{w}$ terminologii wzornictwa przemysłowego proces prowadzący do powstania produktu. Richard Buchanan proponuje, by zaadaptować go również na potrzeby dziedzin innych niż sztuka użytkowa. W artykule zostaje rozpatrzona zasadność owego postulatu w stosunku do nauk społecznych. Autorka analizuje kilka płaszczyzn praktyki badawczej, dla których model myślenia projektowego mógłby stanowić wartościowy punkt odniesienia. Propozycje ich modyfikacji na podstawie design thinking traktuje jako pewne typy idealne i zaproszenie do dalszych dyskusji.

Słowa kluczowe:

design thinking, wicked problems, badania społeczne, interdyscyplinarność, współpraca naukowa

\section{///Abstract}

Design thinking refers to the process of creating a new product. Richard Buchanan proposes to adapt this creative method in the disciplines other than industrial design as well. This article analyzes the possibility of introducing design thinking in social sciences. The author considers various fields of the research practice and modifies them treating design thinking as a key foundation, thus creating some pure types as a basis for further discussion.

Keywords:

design thinking, wicked problems, social research, interdisciplinarity, cooperation in social science 